\title{
ARTÍCULOS
}

\section{EL MOVIMIENTO DE OBJECIÓN DE CONCIENCIA E INSUMISIÓN EN ESPAÑA (1971-2002)*}

\section{The movement of conscientious objection and total objection in Spain}

(1971-2002)

\section{Pedro Oliver Olmo}

Universidad de Castilla - La Mancha pedro.oliver@uclm.es

Orcid: 0000-0001-9787-4641

Cómo citar este artículo/Citation:

Pedro Oliver Olmo, "El movimiento de objeción de conciencia e insumisión en España (1971-2002)”, Hispania Nova, 19 (2021): 353-388

DOI: https://doi.org/10.20318/hn.2021.5885
Copyright: (C) HISPANIA NOVA es una revista debidamente registrada, con ISSN 1138-7319 y Depósito Legal M 9472-1998. Los textos publicados están -si no se indica lo contrario- bajo una licencia Reconocimiento-Sin obras derivadas 3.0 España de Creative Commons. Puede copiarlos, distribuirlos y comunicarlos públicamente siempre que cite su autor y la revista y la institución que los publica y no haga con ellos obras derivadas. La licencia completa se puede consultar en: http://creativecommons.org/licenses/by-nd/3.0/es/deed.es
Resumen: Hacemos una síntesis y un análisis de la movilización antimili y antimilitarista en la España de finales del siglo XX. Se enfoca como un nuevo movimiento social que desarrolló un ciclo de tres décadas de movilización subdividido en seis etapas, entre 1971 y 2002. Los objetores, partiendo de la noviolencia, construyeron una identidad y un consenso ideológico que perduraron gracias a la continuidad ininterrumpida del grupo fundacional, el MOC (Movimiento de Objeción de Conciencia). En la década de 1980 la movilización se diversificó con la creación de los colectivos Mili KK. Los grupos antimilitaristas, entre la rivalidad y la coordinación, compartieron dos valores fundamentales: el antimilitarismo y la desobediencia civil. Fue la perseverancia en la desobediencia civil la que lo hizo singular, históricamente hablando, pues gracias a ella se acentuó la impopularidad de la mili y la crisis del sistema de reclutamiento.

Palabras clave: España Siglo XX, Transición democrática, Antimilitarismo, Objeción de conciencia, Insumisión, Desobediencia civil. 
Abstract: We provide a synthesis and analysis of the mobilisation against military service and militarism in late XX century Spain. This mobilisation is considered as a new social movement that developed a cycle of three decades of mobilisation, subdivided into six stages between 1971 and 2002. The conscientious objectors, basing themselves on nonviolence, built an identity and ideological consensus that persisted thanks to the uninterrupted continuity of the foundational group, the Conscientious Objection Movement (MOC). In the 1980s, the mobilisation diversified with the creation of the Mili KK. But beyond their rivalry and coordination, the antimilitarist groups shared two fundamental values: antimilitarism and civil disobedience. Historically speaking, their singular character was due to their perseverance in practicing civil disobedience, thanks to which they managed to accentuate the unpopularity of military service and bring about the crisis of the recruiting system.

Keywords: XX century Spain, Democratic Transition, Antimilitarism, Conscientious objection, total objection, Civil disobedience.

\title{
INTRODUCCIÓN
}

¿Cómo explicar que en 1991 eclosionara en España una protesta antimili y un movimiento antimilitarista de nuevo cuño? ${ }^{1}$ Quien seguía los medios, sabía que la insumisión aparecía en tertulias, columnas, editoriales, portadas y noticiarios de radio y

\begin{abstract}
* Este artículo es resultado del proyecto titulado "Informe sobre la evolución histórica de los movimientos de objeción de conciencia en Navarra", financiado por el Instituto Navarro de la Memoria (Dirección General de Paz, Convivencia y Derechos Humanos del Gobierno de Navarra) en convenio con la UCLM, y de las tareas incorporadas al proyecto financiado por el MINECO con referencia HAR2016-75098-R.

${ }^{1}$ En este artículo categorizamos "antimilitarismo" en su formulación más inmediata y del tiempo presente, la que identifica a los colectivos que así se autodenominan, un valor compartido que, como se verá, orienta ideológicamente sus rechazos -la mili, los bloques militares, los campos de tiro y las instalaciones armamentísticas, la industria bélica y, en general, la existencia misma de los ejércitospostulando alternativas de "defensa civil" o "defensa popular noviolenta" y un modelo de relaciones humanas plenamente desmilitarizado. En ese sentido, ese discurso forma parte de un debate conceptual que, en el ámbito de las ciencias sociales, se formaliza. La historiografía asume la definición de "antimilitarismo" como expresión de oposición al "militarismo" en su acepción genuina (imposición del poder militar al poder político y la sociedad civil). En España se ha estudiado el militarismo por su vinculación con el orden público, la política, la justicia, la economía y, en fin, la guerra. También existe una interesante bibliografía que observa la evolución histórica del antimilitarismo junto a conceptos complementarios, como "pacifísmo" o "civilismo". La idea de "civilismo" logra sortear la identificación de lo "militar" con el "militarismo", porque valora la práctica militar que consigue quedar subordinada al poder político (en el caso español, véase: Carlos Seco Serrano, Militarismo y civilismo en la España contemporánea, Instituto de Estudios Económicos, Madrid, 1984). El "pacifismo", muy conocido como nuevo movimiento social de finales del siglo XX, cuenta con pocos estudios referidos a etapas anteriores, a pesar de su importancia en la historia social, como señala: Mario López-Martínez, "Historia de la paz en acción: el pacifismo de los salones a las calles (1889-1939)", Vínculos de Historia, $\mathrm{n}^{\circ} 7$ (2018), pp. 79-96 (versión on line: $\mathrm{http} / / /$ vinculosdehistoria.com/index.php/vinculos/article/view/vdh 2018.07.05). Acerca de la aplicabilidad historiográfica en España de la noción clásica de "antimilitarismo", destacamos: Rafael Núñez Florencio, Militarismo y antimilitarismo en España (1888-1906), CSIC, Madrid, 1990). Sería harto prolijo relacionar aquí las obras referenciales que han considerado el antimilitarismo por su relación (a veces contradictoria) con distintos colectivos de izquierda, libertarios, antiautoritarios y contraculturales.
\end{abstract}


TV. Protagonista también de la agenda cultural (en actos académicos, en conciertos y teatros, en chistes y tiras cómicas, y en el cómic, los grafitis o los murales callejeros), "el insumiso" estaba siendo construido como figura social. Entre tanto, tal y como buscaban los colectivos antimilitaristas y de objeción de conciencia, la insumisión, como campaña de desobediencia civil a la mili (y al servicio civil), influía en las agendas de poder, las cuestionaba y las desordenaba, tanto las gubernamentales (con el ejército en entredicho), como las judiciales (rebasadas por un fenómeno contestatario que seguramente no hubieran deseado ver sentado en las salas de justicia). El movimiento antimilitarista estaba culminando un proceso que conseguía "abrir, reconducir y bloquear la agenda oficial" en materia de objeción de conciencia y servicio militar obligatorio ${ }^{2}$.

Es verdad que 1991 no fue un año cualquiera. La notoriedad de la insumisión se agigantó al compás de los tambores de guerra que sonaban en el Golfo Pérsico. Pero aquella fama no surgía simplemente porque se estuviera atravesando una coyuntura especial. No se entendería esa movilización sin una mirada retrospectiva, de década en década: diez años atrás, en 1980, los objetores celebraban que con su presión no hubiera prosperado el proyecto de ley de objeción de UCD; y veinte años antes, a comienzos de la década de 1970, un puñado de jóvenes pacifistas dieron a conocer un tipo de objeción de conciencia subversiva para el franquismo.

En este artículo, una vez más, utilizamos las categorías analíticas de la sociología de los nuevos movimientos sociales (es el marco teórico que en gran media orienta nuestra investigación histórica) ${ }^{3}$. Las incorporamos a la caja de herramientas de la investigación histórica ${ }^{4}$. Secuenciamos el tiempo largo de una agitación prolongada, que aconteció entre una dictadura y una democracia, a caballo de períodos políticos

\footnotetext{
${ }^{2}$ Víctor Sampedro, Movimientos sociales: debates sin mordaza. Desobediencia civil y servicio militar (1970-1996), (Madrid: Centro de Estudios Constitucionales, 1997), pp. 297 y ss.

${ }^{3}$ Las investigaciones académicas (sociológicas, jurídicas e historiográficas) que se han centrado en el estudio de este movimiento, muchas de las cuales se realizaron cuando la movilización estaba en curso o aún no había llegado a su última etapa, se han inspirado directamente en este referente teórico o lo han tenido muy en cuenta (véase sobre todo las obras de Sidney Tarrow, El poder en movimiento. Los movimientos sociales, la acción colectiva y la política, (Madrid: Alianza, 2004); y Doug McAdam, John D. McCarthy y Mayer N. Zald, M., Movimientos sociales: perspectivas comparadas, (Madrid: Istmo, 1999).

${ }^{4}$ Manuel Pérez Ledesma, “ $<<$ Nuevos $>>$ y $<<$ viejos $>>$ movimientos sociales", en Carme Molinero (ed.), La transición, treinta años después, (Barcelona: Península, 2006), pp. 117-151. Comenzó a teorizarlo Pedro Ibarra en: "Un nuevo movimiento social”, Papeles para la Paz, número 38 - 1990, pp. 229-237.
} 
distintos y a lo largo de tres décadas de cambios sociales. Se identifican seis etapas (con duraciones diferentes, alguna de ellas entre los años bisagra de dos décadas). Son seis subciclos de movilización que constituyen la experiencia organizativa (sólida e informal, cambiante pero perdurable) de un nuevo movimiento social. En su vertiente amplia, política e ideológica, se describe como movimiento pacifista y antimilitarista (con esos mimbres continuará su trayectoria una vez suspendida la mili) ${ }^{5}$. Pero en su dimensión reducida, experiencial e identitaria, por su papel en la movilización contra la conscripción militar, lo correcto es definirlo como movimiento de objeción e insumisión ${ }^{6}$. Esa pequeña conjunción copulativa, con la que se unen dos décadas a favor de la objeción de conciencia y otra centrada en la insumisión, se convierte en la clave historiográfica que identifica a este movimiento social a lo largo del ciclo entero de movilización.

Este artículo ofrece una síntesis del proceso completo. Faltan detalles que quedan contenidos en el aparato crítico, seleccionado por su valor referencial, aunque añadimos algunas fuentes hemerográficas para documentar las últimas etapas, por estar menos investigadas. Está estructurado en tres apartados, uno por década, y comienzan con un análisis de la estructura de oportunidad política durante cada decenio, a lo que siguen dos subapartados dedicados a la estructura de movilización, con especial atención a los valores (compartidos o en disenso) y a los repertorios de acción en cada etapa.

\section{AÑOS 70: LA OBJECIÓN DE CONCIENCIA COMO PROBLEMA POLÍTICO}

Para los gobiernos de la dictadura y de la Transición la objeción de conciencia

\footnotetext{
${ }^{5}$ Pedro Ibarra, Manual de sociedad civil y movimientos sociales, (Madrid: Síntesis, 2005. En enero de 2003, el MOC (Movimiento de Objeción de Conciencia) pasó a denominarse Alternativa AntimilitaristaMOC (https://www.antimilitaristas.org/Declaracion-ideologica-de-Alternativa-AntimilitaristaMOC.html).

${ }^{6} \mathrm{Si}$ hemos de aportar un texto fundamental que documente esta idea, leamos el "Manifiesto de los insumisos" de febrero de 1989, donde quedaba definida la identidad del "objetor insumiso" desde el comienzo: "Los objetores de conciencia que estamos recibiendo órdenes de incorporación al Ejército... Manifestamos: 1) Que hacemos objeción de conciencia negándonos a cumplir el Servicio Militar" (véase en: MOC, En legitima desobediencia. Tres décadas de objeción, insumisión y antimilitarismo, (Madrid: Traficantes de Sueños, 2002, pp. 171-172). Al día siguiente de aquella primera presentación de insumisos pudo leerse en El Pais: <<Los objetores que se niegan a cumplir el servicio militar se autodenominan "insumisos", rechazando las expresiones "desertores" o "prófugos">> (El País, 21 de febrero de 1989).
} 
fue un problema, no un derecho. Lo enfocaron siempre como un delito ${ }^{7}$. En todo caso como una provocación. Si Franco nunca quiso que pasara del umbral de la excepcionalidad religiosa, por su parte, los gobiernos de la democracia también la coartaron como derecho. Para todos era un fenómeno entre extravagante y embarazoso, un indeseable problema de Estado que podía colisionar con eventuales reacciones conservadoras dentro del ejército. Comenzó con la imagen comprometedora de los Testigos de Jehová, encarcelados una y otra vez por un escrúpulo de conciencia que imponía su propia obediencia religiosa. Ahora bien, cuando el Estado franquista quiso regular (y adaptar el castigo) de una opción que querían reducir al terreno de la conducta personal, se generó una estructura de oportunidad que aprovecharon otros objetores de conciencia que no eran Testigos de Jehová. Con el "caso Beunza" emergió un tipo de objeción de conciencia pacifista, que el franquismo interpretó en clave ideológica, lo que provocó un insólito impacto político ${ }^{8}$.

Esta problemática le sobrevino al franquismo en sus últimos años, precisamente, porque la objeción de conciencia apelaba irremisiblemente a derechos humanos que la dictadura era capaz de negar o reducir a la vez que reconocer y regular legalmente. Y así, con el telón de fondo de los efectos provocados por la limitada Ley de libertad religiosa de 1967 y por las ideas modernizadoras del general Díez Alegría en materia de organización de los ejércitos, la objeción de conciencia empezó a vislumbrarse en la mentalidad de los mandos militares y muchos mandatarios políticos como un asunto delicado, entre provocador y engorroso, por lo que comenzaron a abordar su regulación. En principio, únicamente se pensaba en los reclutas que se declaraban Testigos de Jehová. Aquella creencia minoritaria, con la nueva ley y a pesar de la atmósfera represiva, ganaba oportunidades para su crecimiento. En 1970 ya había 35 Testigos de Jehová en prisiones militares y la cifra iba a seguir aumentando ${ }^{9}$. Entre 1970 y 1971, el gobierno quiso legislar sobre esa situación anómala al asumir que la legislación militar chocaba directamente con la creciente presencia de objetores por motivos religiosos,

\footnotetext{
${ }^{7}$ Carlos Ángel Ordás García, “Traidores a la patria. Objetores e Insumisos en España, 1958-1991”, Clio \& Crimen, 14 (2017): 209-226.

${ }^{8}$ Pedro Oliver Olmo, P. La utopía insumisa de Pepe Beunza. Una objeción subversiva durante el franquismo, (Barcelona: Virus, 2002).

9 Jesús Jiménez, La objeción de conciencia en España, (Madrid: Cuadernos para el Diálogo, 1973), p. 218.
} 
porque obligaba a sentenciarlos a "condenas en cadena" $"$. Pero, si legalmente ya existía un arduo problema, con la irrupción de los "otros" objetores, todo se complicaría políticamente mucho más.

Las iniciativas gubernamentales de 1970 y 1971 no consiguieron el objetivo de encauzar controladamente el asunto. El problema quedó trastocado con la aparición de ese nuevo tipo de objetor pacifista, lo que a su vez instigaba al bunker y a la prensa ultra a oponerse de manera furibunda y conseguir que la regulación de la objeción de conciencia no saliera adelante ${ }^{11}$. A propósito de esta cuestión se vivió un ambiente bronco, en gran medida azuzado por el protagonismo de Blas Piñar ${ }^{12}$. Dos años más tarde, en medio de una auténtica polémica política y periodística, que se retroalimentaba al calor de las campañas públicas de apoyo a los nuevos objetores pacifistas, volvió a debatirse, en la Comisión de Defensa de la Cortes, un Proyecto de Ley sobre negativa a cumplir el Servicio Militar. Fue un asunto que acarreó disputas y divisiones en la "agenda elitista" del franquismo ${ }^{13}$. Con la Ley 14/73, el régimen conseguía quitarse de encima el problema legal de las "condenas en cadena", pero lo hacía acentuando la vía penalizadora y con ello dejaba sin resolver (o pendiente de agravamiento, según se comprobó después) el problema de fondo: el artículo 383 bis del Código de Justicia Militar permitiría desde entonces imponer penas de 3 a 8 años y una especie de "muerte civil" a los reclutas que se negaran a ir a la mili ${ }^{14}$. Quedaban en libertad los "soldados corrigendos" que penaban su desobediencia en los castillos militares y de un plumazo se desdramatizaba el destino punitivo de los Testigos de Jehová. Pero no es menos cierto que también se desenmarañaba el camino de la agitación política para los objetores de conciencia pacifistas.

De esa manera llegaría la situación legal y política de los objetores de conciencia al primer período de la Transición. Legalmente estancada pero no desactivada. La más mínima muestra de activismo de los pacifistas, por testimonial que fuera, hubo de

\footnotetext{
10 Joan Oliver Araujo, La objeción de conciencia al servicio militar, (Madrid: Universitat de les Illes Balears-Cívitas), 1993.

${ }^{11}$ Pere Ortega, La societat noviolenta. Converses amb Pepe Beunza, (Barcelona: Icaria-ICIP, 2012.

12 Pedro Oliver Olmo, La utopía insumisa... (capítulo 17, titulado "Los objetores y los ultras. El caso Beunza en las Cortes franquistas").

13 Acerca de la incidencia de los objetores pacifistas en la "agenda franquista": Víctor Sampedro, Movimientos sociales..., p.115 y ss.

${ }^{14}$ José Luís Lafuente, Jesús Viñas, Los objetores. Historia de una acción, (Madrid: Cares, 1977).
} 
provocar reacciones hostiles en los cuarteles. No era una situación grata para nadie, pero el proceder del gobierno franquista, represivo e inmovilista a la vez, no amilanaba al incipiente movimiento de objeción, el cual, muy pronto, en 1975, iba a repensar y reconducir la estrategia de la desobediencia civil para realizarla de manera colectiva. Después de que la primera amnistía sacara a los objetores de la cárcel, Suárez amagó con un Real Decreto sobre Objeción de Conciencia que estaba muy lejos de poder homologarse con la legislación democrática de otros países europeos ${ }^{15}$. No cambiaba nada. Solamente la reconocía por motivos religiosos al tiempo que imponía al recluta objetor un servicio civil de tres años. Eso reactivó la protesta de los colectivos de objeción. La agitación de los grupos de objeción de conciencia aumentó desde la creación del MOC, en enero de 1977, mientras que el gobierno no llegaba a dar una respuesta a sus reclamaciones y los objetores seguían entrando en prisión, hasta la amnistía de octubre. Con la sensación de estar frente a un callejón sin salida, el gobierno Suárez asumía de hecho el aplazamiento de la resolución del problema, hasta que se reconociera constitucionalmente el derecho a la objeción de conciencia y se regulara la Prestación Social. Pero la meta legislativa no podría soslayar el umbral problemático en el que había quedado ubicado, entre la espada de los mandos militares y la pared de los objetores organizados. Y por eso tampoco se resolvería cuando, en abril de 1978, la UCD presentó un proyecto de Ley que los objetores rechazaron con firmeza, apostando nuevamente por la desobediencia. El proyecto quedó aparcado dos años y cuando fue presentado de nuevo y algo modificado, en 1980, con la presión del MOC como telón de fondo, recibió tantas enmiendas del PSOE, el PCE y los nacionalistas, que tampoco pudo prosperar.

La realidad contante y sonante era que, desde noviembre del 77, en virtud de una orden interna que el vicepresidente Gutiérrez Mellado había dirigido a los cuarteles, los mozos que se declararan objetores quedarían "en incorporación aplazada", y aquellos otros que lo hicieran de manera sobrevenida estando ya en filas, obtendrían una licencia provisional. Se abrió un largo paréntesis ${ }^{16}$. Quizás pensaron que se estaba soterrando un problema de exiguas minorías. Nadie vislumbraba entonces un conflicto social en torno a la mili. Pero, objetivamente, el inmovilismo heredado del franquismo, al prolongarse

\footnotetext{
${ }^{15}$ Rafael Ajangiz, Servicio Militar obligatorio en el siglo XXI: cambio y conflicto, (Madrid: CIS, 2003).

${ }^{16}$ Xavier Rius, La objeción de conciencia: motivaciones, historia y legislación actual, (Barcelona: Editorial Integral, 1988).
} 
durante la Transición, beneficiaría mucho a un nuevo movimiento social en construcción.

\section{$1^{\text {a }}$ etapa (1971-1976): Los iniciadores}

Debemos considerar la importancia de la organización desde sus inicios, aunque fuera un movimiento embrionario y con estructuras quebradizas, forzosamente clandestino. Así hubo de transcurrir entre 1971 y 1976, a caballo de los dos hitos que delimitan esta primera etapa, las dos campañas más genuinas del inicio del ciclo de movilización: la del apoyo a Pepe Beunza, en 1971; y la que en 1976 llevaron a cabo los objetores del primer servicio civil autogestionario en el barrio de Can Serra ${ }^{17}$.

Los primeros objetores pacifistas parecían casos aislados y singulares que emergían en el pequeño caldo de cultivo de las agitaciones antifranquistas y de las oportunidades que generaba el propio régimen, con sus intentos fallidos de legislar en esa materia. Pero no fue así como surgió todo. Para entender bien el papel que iba a cumplir el primer objetor, Pepe Beunza, más que atender a su caso particular, debe valorarse "la campaña de Pepe Beunza". ¿Quién estaba detrás? Algunos militantes de grupos cristianos críticos con el régimen y activistas de la noviolencia como Gonzalo Arias y los seguidores de la francesa Comunidad del Arca más sus redes de colaboradores europeos ${ }^{18}$. Mediante esa campaña lograron construir una noción de la objeción de conciencia que no ponía el énfasis en lo religioso e individual, pese a que aquellos primeros objetores fueran jóvenes católicos (a su vez críticos con la jerarquía de la Iglesia católica). Era una objeción que se proyectaba hacia lo ético y lo colectivo, al servicio de los sectores más necesitados de la sociedad, por lo que su actitud y su discurso enseguida adquirían resonancias políticas que, en el contexto de una dictadura, la representaban como un derecho democrático. Aquella objeción nacía de una apuesta ideológica por la paz y la justicia, contra la guerra y sus causas. Estratégicamente, era la

\footnotetext{
${ }^{17}$ Pedro Oliver Olmo, "Los iniciadores del movimiento de objetores de conciencia (1971-1977)", en Manuel Ortiz Heras (Coord.), Culturas políticas del nacionalismo español: del franquismo a la transición, (Madrid: Los libros de la Catarata, 2009), pp. 219-244.

18 Sobre el porqué del uso de "noviolencia" en vez de "no violencia" o "no-violencia", véase: Jesús Castañar Pérez, Breve historia de la acción noviolenta, (Madrid: Pentapé, 2010); Jesús Castañar Pérez, Teoría e Historia de la Revolución Noviolenta, (Barcelona: Virus, 2014) (el autor ofrece un estado de la cuestión y aborda la gran variedad de posiciones éticas, filosóficas y políticas que existen al respecto).
} 
primera campaña que apostaba por la desobediencia civil, por la acción noviolenta y por la búsqueda de complicidades y apoyos en la sociedad civil a nivel nacional e internacional. Se puso en práctica una dinámica de acción política con dos vertientes complementarias: la práctica de la desobediencia civil y la reclamación de la objeción de conciencia como un derecho fundamental que debía regularse a través de servicios civiles cuyos fines fueran la utilidad social y la defensa de la paz y el desarme, una idea que llevarían a la práctica también como herramienta de agitación cuando organizaron sus propios servicios civiles autogestionarios ${ }^{19}$.

Pepe Beunza, al acabar su calvario disciplinario en 1974, junto con Gonzalo Arias, el veterano activista de la noviolencia, organizaron una mínima red de colaboración entre grupos, con el fin de iniciar una larga campaña de concienciación titulada Voluntariado para el Desarrollo. Había grupos en Barcelona, Tarragona, Vic, Valencia, Bilbao, Pamplona, Madrid, Málaga, etcétera. Así comenzó a prepararse la siguiente campaña de desobediencia, la que protagonizaron cinco objetores que, a finales de 1975, hicieron pública su negativa a hacer la mili con argumentos pacifistas y de utilidad social que fundamentaban la realización de un servicio civil alternativo en el barrio de Can Serra, en L'Hospitalet, consistente en trabajos comunitarios y de apoyo al movimiento ciudadano. Cuando ese reto al Estado llevó a los objetores a la prisión militar de Figueras en febrero de 1976, tal y como también estaba previsto por parte de los grupos de apoyo a la campaña, comenzaron las acciones de solidaridad con los presos de conciencia.

Por lo tanto, en los inicios del proceso de transición de la dictadura a la democracia, ya existía una mínima estructura de grupos y personas, una red de colectivos con un bagaje de experiencias y con militantes activos ${ }^{20}$. La desobediencia civil y la noviolencia eran valores compartidos que orientaban el repertorio de sus acciones colectivas. Contaban con los componentes propios de un nuevo movimiento social, lo que ayudó a darles cierta visibilidad en una época de cambios rápidos y profundos. En julio de 1976, se beneficiaron del decreto de indulto, al igual que los presos políticos. Y en aquella coyuntura tan dinámica, frente a la parálisis oficial con la

\footnotetext{
${ }^{19}$ Carlós Angel Ordás García, «L’objecció de consciència durant el franquisme i la Transició. Dissidència política i xarxa de suport», Franquisme \& Transició, 4 (2016): pp. 41-87.

${ }^{20}$ Enric Prat, Moviéndose por la paz. De Pax Christi a las movilizaciones contra la guerra, (Barcelona: Hacer, 2003).
} 
cuestión de la objeción de conciencia y en el caldo de cultivo de las movilizaciones democráticas, los objetores organizados tuvieron más posibilidades que antes. Era fácil deducir la oportunidad histórica que les ofrecía el hecho de haber quedado como una suerte de asignatura pendiente. Simplemente tenían que reestructurarse y crecer en unas nuevas coordenadas políticas. Y comenzar otra etapa.

\section{$2^{a}$ etapa (1977-1982): EI MOC}

En el ambiente político de enero de 1977, convulso e incierto e incluso amenazante para el proceso de transición de la dictadura a la democracia, cuando en España hervían todas las militancias y se excitaban todas las protestas, cuando se empujaba desde abajo hacia la ruptura democrática, también se constituyó el MOC. Nació como coordinadora de grupos, pero desde el principio fue palmaria su identidad y vocación favorables a la creación de un movimiento social. En adelante, y a lo largo de toda su historia, funcionaría con métodos de participación democrática, horizontales y asamblearios. Algunos grupos se estaban formando y aún no asistían, pero en su constitución participaron muchos colectivos de todo el país, de entre los que destacaron tres núcleos con un activismo más veterano: Barcelona, Madrid y Bilbao. En el MOC confluyeron personas y grupos que compartían valores específicos e incluso proyectaban un cierto estilo en las formas de la acción colectiva. En realidad, había una variedad de culturas políticas, pero primaba la necesidad de estar unidos por dos objetivos políticos de hondo calado: 1) hacer valer la reclamación del derecho a la objeción de conciencia, más aún durante el proceso de democratización; y 2) apostar por la desobediencia civil como herramienta de presión.

El MOC, como coordinadora que vehiculaba el movimiento de objeción de conciencia en su sentido amplio, además de continuar su relación con el movimiento estudiantil (muy fluida desde la presencia de Pepe Beunza en el Sindicato Democrático de Estudiantes), se acercó a las reclamaciones de otros movimientos sociales que empezaban a eclosionar, como el feminista y el ecologista ${ }^{21}$. Al denominarse Movimiento de Objetores y Objetoras de Conciencia quería trasmitir que su lucha no concernía exclusivamente a jóvenes varones conscriptos, sino a hombres y mujeres con

\footnotetext{
${ }^{21}$ Carme Molinero y Pere Ysàs, La Transición: Historia y Relatos, (Madrid: Siglo XXI, 2018), p. 241.
} 
valores antimilitaristas y antiautoritarios que dirigían contra el patriarcado en general y el machismo de los ejércitos en particular. Habiendo recibido su primer impulso del cristianismo social, ahora se entramaba con el feminismo, el ecologismo, el anarquismo $\mathrm{y}$, en menor medida, con el marxismo heterodoxo. No empatizaba ni con las izquierdas nacionalistas ni con las constitucionalistas, y, hasta los años 80, tampoco con las revolucionarias $^{22}$. Las izquierdas moderadas ya no podían asumir la peculiar radicalidad de un movimiento de desobediencia civil, y la izquierda radical aún no podía entenderla.

La experiencia anterior hubo de notarse mucho en el peso de los valores y los referentes ideológicos ${ }^{23}$. El primer MOC se nutría de grupos que habían protagonizado la primera etapa. Su doble naturaleza -MOC eran las siglas de una coordinadora estatal pero también podían ser las de un colectivo concreto- era un motivo de debate acerca de su identificación ideológica. En determinados casos, las distancias denotaban interpretaciones antimilitaristas propias, como ocurrió en el colectivo barcelonés GANVA (Grup d’Acció No Violenta Anti-OTAN), más adelante GAMBA (Grupo Antimilitarista de Barcelona), cuyo liderazgo ideológico se notaría mucho dentro del MOC e irradiaría hacia el conjunto del movimiento antimilitarista. Si se repasa el mapa estatal se observa que, entre 1977 y 1979, existía un auténtico movimiento pacifista y antimilitarista en España dentro del cual descollaba la presencia y el dinamismo del MOC, con raigambre en Cataluña, Valencia, Andalucía, Madrid, Euskadi y Navarra, dejando su impronta en otros muchos lugares, en Zaragoza, Murcia, Albacete, Canarias, Galicia, Valladolid, Extremadura... ${ }^{24}$

Muchos de sus integrantes eran pacifistas cristianos. Defendían una noviolencia ética y política que se inspiraba en el mensaje de Gandhi que llegaba a través de uno de sus discípulos, el cristiano Lanza del Vasto, además de las experiencias de Martin

\footnotetext{
${ }^{22}$ Carlos Ángel Ordás García, "La soledad de los primeros pacifistas. Incomprensión de las izquierdas y apoyos de sectores proconciliares" (comunicación presentada en VIII Encuentro Internacional de Investigadores del Franquismo, Barcelona, 21 y 22 de noviembre de 2013). Véase on line en:

https://www.dropbox.com/sh/evt0ds93oy05p11/AADoutYAIaAHAYQ9vzw EuiQa?preview=Ord\%C3\% A1s $\% 2 \mathrm{C}+$ Carlos $+\% \mathrm{C} 3 \% 81$ ngel.pdf.

${ }^{23}$ Se hacía balance de lo ocurrido entre 1971 y 1976 en el libro titulado Objeción de conciencia: otro servicio, (Barcelona: Cuadernos edebé, Ediciones Don Bosco, 1977).

${ }^{24}$ Pedro Oliver Olmo, "El movimiento pacifista en la transición democrática española", en Rafael Quirosa-Cheyrouze (ed), La sociedad española en la Transición. Los movimientos sociales en el proceso democratizador, (Madrid: Biblioteca Nueva, Madrid, p. 277. Véase también: John Paul Lederach, Els anomenats pacifistes. La noviolència a l'Estat espanyol, (Barcelona: Pagès editors, 1983); y Cythia Cockburn, Antimilitarisme. Dinàmiques polítiques $i$ de gènere dels moviments per la pau, (Barcelona: Pagès editors, 2014).
} 
Luther King y de los refractarios franceses a la guerra de Argelia, entre otros testimonios de noviolencia normalmente más vivenciales que intelectuales (Danilo Dolci, César Chávez, Herder Cámara, etcétera). Ahora bien, en el MOC inicial también estaban ya los activistas de un antimilitarismo genuinamente libertario que diversificaba y estimulaba aún más el debate interno. Dentro del MOC se discutía sobre noviolencia y antimilitarismo como puntos de referencia primordial complementarios o contrapuestos, y sobre el papel revolucionario o gradualista de la desobediencia civil, mientras se reclamaba una ley cuya mera mención, por aquel entonces, chocaba con la presión que ejercía el ejército ${ }^{25}$. Los motivos de disenso se agudizaban conforme las siglas del MOC tomaban cuerpo como representación del movimiento de objeción de conciencia propiamente dicho, en toda su amplitud y en toda su variedad. Aunque la posición de partida era expresamente contraria a "toda conscripción", en un alarde de posibilismo que con el tiempo iba a ser internamente cada vez más cuestionado por contradictorio, el MOC consentía que una ley de objeción de conciencia pudiera regular tanto el derecho a la misma como la obligación de realizar una prestación sustitutoria, aunque en ese caso, como mínimo, la ley debía incorporar los llamados “12 puntos básicos” que la asamblea estatal del MOC logró consensuar en la primavera de 1978. A modo de líneas rojas, esas condiciones orientarían los discursos del MOC hasta los primeros años ochenta: que no hubiera un "tribunal" que juzgara la conciencia del objetor, que se reconocieran también los motivos políticos, que el servicio civil no durara más que el militar, que se aceptara la objeción sobrevenida, que el servicio civil estuviera desmilitarizado y no perjudicara a la clase trabajadora... ${ }^{26}$ Hubo otras líneas de actuación que empezaron a ser más estimulantes para la militancia a la hora de ser consensuadas: analizar y divulgar las funciones sociales de los ejércitos y del servicio militar, realizar acciones noviolentas en las oficinas municipales de reclutamiento o en instalaciones militares, y acompañar con concentraciones a los objetores que acudían a las cajas de recluta y a los gobiernos militares el día que rechazaban el petate $\mathrm{y}$, en consecuencia, eran declarados en incorporación aplazada. El MOC profundizó en el discurso de la “desmilitarización

\footnotetext{
${ }^{25}$ Sobre la presión del ejército en la Transición, véase: Felipe Agüero, Militares, civiles y democracia. La España postfranquista en perspectiva comparada. (Madrid: Alianza, 1995; Xavier Casals, La Transición española. El voto ignorado de las armas, (Barcelona: Pasado y Presente, 2016); etcétera.

${ }^{26}$ Con ese argumentario se rechazaron las leyes de UCD y PSOE. Véase: MOC. En legítima desobediencia. Tres décadas de objeción, insumisión y antimilitarismo, (Madrid: Traficantes de Sueños, 2002), pp. 87 y 92.
} 
social", a través de campañas "contra el juguete bélico, sexista y sofisticado", con la difusión de la educación para la paz y mediante la práctica de la "objeción fiscal" en la declaración de la renta.

El primer Congreso (Landa, 1979) fue emblemático para la evolución ideológica del MOC. El pensamiento antimilitarista se consolidaba a la vez que se agrietaban acuerdos "básicos", como la realización de servicios civiles autogestionarios y la reivindicación de una ley de objeción, lo que derivó en posiciones disidentes de objetores "históricos" que muy pronto, hacia 1980, quedarían escindidas y minimizadas. La discrepancia connotaba una doble tensión: en torno a la ideología (o un pacifismo moderado o un antimilitarismo radical) y acerca de la estrategia política (o un "sindicato de objetores" o un movimiento rupturista ${ }^{27}$. El MOC, a pesar de que crecía el número de grupos, se quedó atascado en debates recurrentes que tuvieron que ser aparcados para afrontar situaciones extraordinarias y al menos dos serias emergencias: $1^{\text {a }}$ ) el encarcelamiento en febrero de 1980 de un objetor sobrevenido y otros 20 objetores bilbaínos que, al solidarizarse, fueron acusados de injurias al ejército; y $2^{\mathrm{a}}$ ) la intención de UCD de sacar adelante en 1980 un proyecto de ley de objeción. Entre 1979 y 1982 , el MOC afrontó un curioso impasse organizativo, en el que, paradójicamente, parecían coexistir todas las posturas y todas las divisiones internas.

\section{AÑOS 80: UNA LEY DE OBJECIÓN DE CONCIENCIA BOICOTEADA}

El triunfo del PSOE en las elecciones de octubre de 1982 abrió un período de cambios políticos (también de índole militar) que incidirían directamente en el desarrollo de la objeción de conciencia al servicio militar obligatorio, un fenómeno que progresaba, al calor de las mudanzas culturales de la nueva década, con el empuje de un movimiento que se expandía e incluso creaba coordinadoras de ámbito autonómico (vasco, catalán, andaluz, etcétera). Los colectivos de objetores, más allá de la recurrencia de sus debates internos, a partir de 1983 crecían en un caldo de cultivo propicio. Por un lado, con el ruido de fondo de las tramas golpistas que sobrevivieron al 23-F, se estaba agravando la crisis de imagen del ejército español, lo que afectaba cada

\footnotetext{
${ }^{27}$ Una revisión desde los años 80 en: Rafael Sainz de Rozas, "Razones y vivencias del objetor y del insumiso", Papeles. Cuestiones internacionales de paz, ecología y desarrollo, CIP, 54 (1995): pp. 37-44.
} 
vez más al descrédito del sistema de reclutamiento ${ }^{28}$. Y por otro, en toda Europa se estaba asistiendo a un gran cambio en las actitudes sociales hacia la geopolítica de la Guerra Fría, lo que pudo palparse de manera multitudinaria con las protestas pacifistas contra el despliegue de los euromisiles y, en España, con la campaña contra la OTAN y las bases americanas.

Esto último, que a su vez estaba relacionado con el influjo de la irrupción de Los Verdes en Alemania, fue bien interpretado por el MC (Movimiento Comunista) y la LCR (Liga Comunista Revolucionaria), lo que les permitió liderar la campaña antiOTAN, de lo cual, fue una muestra elocuente la creación en julio de 1983 de la CEOP (Coordinadora Estatal de Organizaciones Pacifistas) ${ }^{29}$. Pero también sopló en beneficio de la capacidad de influencia política del MOC, en dos direcciones: hacia el PSOE, que continuó considerándolo interlocutor en materia de objeción (algo que seguía enfocando como un problema); y hacia la izquierda radical, que básicamente aceptó el liderazgo histórico e ideológico del MOC en un movimiento que también querían dinamizar, sobre todo entre la juventud. En medio de la agitación anti-OTAN, la izquierda revolucionaria comenzó a promover la movilización antimilitarista mediante la creación de los colectivos Mili KK. El fuerte impacto de la campaña anti-OTAN en el desarrollo histórico del movimiento de objeción de conciencia fue notorio y así se ha destacado por parte de la investigación especializada. Podemos colegir que influyó decisivamente en dos sentidos: hacia fuera, sobre todo en el trabajo con otros movimientos sociales, porque ayudó a difundir propuestas antimilitaristas como la objeción fiscal, y hacia dentro, porque animó de manera decisiva a los sectores más radicales en el camino hacia la insumisión ${ }^{30}$.

\footnotetext{
${ }^{28}$ Las encuestas indicaban un bajo índice de "patriotismo" y una clara desatención de los ciudadanos hacia la cultura de defensa (Juan Díez Nicolás, Identidad nacional y cultura de defensa, (Madrid: Síntesis, 1999).

${ }^{29}$ Acerca del papel de la izquierda revolucionaria hay una bibliografía que omitimos por razones de espacio (Jaime Pastor, Gonzalo Wilhelmi, Pablo Socorro Arencibia, Isabel Ma Cubero Trujillo, José E. Pérez Martinez, etc.). Sobre la CEOP, véase: https://archivodelatransicion.es/archivoorganizaciones/archivo-movimiento-anti-otan.

${ }^{30} \mathrm{La}$ variedad de organizaciones en la movilización anti-OTAN y la presencia del movimiento de objeción, en: Enric Prat, Moviéndose por la paz. De Pax Christi a las movilizaciones contra la guerra, (Barcelona: Hacer, 2003.
} 
Además de los grupos nacionalistas catalanes y vascos, el PSOE había sido una suerte de aliado del MOC en el rechazo de los proyectos de ley de $\mathrm{UCD}^{31}$. Pero una vez en el gobierno, en 1983, presentó una propuesta legislativa que resultó ser diferente, entre decepcionante y regresiva. E1 MOC rápidamente rechazó aquella Ley de Objeción de Conciencia (LOC) y amenazó con no acatarla. La promulgación de la LOC había llegado por sorpresa el día de los Santos Inocentes de 1984, cuando en líneas generales, y sobre todo en las provincias vascas, Navarra y Cataluña, las cifras de objetores se incrementaban significativamente, lo cual, a pesar de la incertidumbre que provocaba la apuesta por la desobediencia civil -el miedo a la represión y la marginalidad-, era un buen punto de apoyo para poner en práctica lo que venían defendiendo algunos colectivos de dentro y de fuera del MOC (especialmente el GAMBA): una campaña de “objeción colectiva". Los disensos internos llevaron al MOC a acordar una doble estrategia que, aunque ideológicamente denotaba contradicciones, resultó ser políticamente complementaria: por un lado, se convenció al Defensor del Pueblo para que presentara un recurso de inconstitucionalidad, lo que, en la práctica, dejaría suspendida la aplicación de la ley; y por otro, se apostó por la desobediencia civil bajo la forma política de la "objeción colectiva", con la táctica de la "carta colectiva".

La campaña de la "carta colectiva" comenzó en 1985 y rápidamente alcanzó un éxito rotundo, lo que ponía al Estado en un brete. Aunque pronto se supo que el mayor grupo de objetores seguía siendo el de los Testigos de Jehová que habían cumplimentado la instancia requerida por la LOC, a nadie se le escapaba que el resto, casi en su totalidad, firmaba una misma carta y con ella una misma estrategia que se lanzaba a la opinión pública como un reto al Estado. La carta colectiva era un documento dirigido al Consejo Nacional de la Objeción de Conciencia (CNOC) que el objetor firmaba individualmente para declarar que estaba al margen (y en contra) de la ley. Se hacía real así el lema "o todos o ninguno", una táctica proactiva que el movimiento de objeción e insumisión tendría que volver a utilizar en el futuro en distintos momentos del ejercicio de la desobediencia civil. Aquello era un boicot (político y normativo) en toda regla. Sin embargo, el CNOC "renunció a su papel de

\footnotetext{
31 Víctor Sampedro, Movimientos sociales: debates sin mordaza. Desobediencia civil y servicio militar (1970-1996), (Madrid: Centro de Estudios Constitucionales, 1997), pp. 154, 166.
} 
criba" ${ }^{32}$. Encaró el reto dando una respuesta de no confrontación y aceptando como objetores a miles de firmantes de la carta (y comoquiera que, con más de 3.000 cartas colectivas presentadas el primer año, más de un tercio del total de objetores seguía la estrategia antimilitarista, se calculaba un potencial de desobediencia de más del $86 \%)^{33}$. La grieta estaba abierta, y por ella seguirían entrando objetores -más de 9.000dispuestos a no colaborar, mientras que la gestión administrativa se estancaba, esperando al Tribunal Constitucional.

Había motivos de preocupación para el gobierno: por un lado, los grupos antimilitaristas tenían fácil conseguir eco mediático y ahondar en la impopularidad del servicio militar; y por otro, el movimiento social que azuzaba aquel conflicto se reestructuraba y fortalecía. La estrategia de la objeción colectiva espoleaba las expectativas de incremento de la objeción de conciencia, a lo que ayudaba el clima político favorable al pacifismo que se había creado durante la campaña anti-OTAN (coincidente con el auge del movimiento pacifista en Europa), además de la mala imagen del ejército tras el 23-F y el creciente desafecto juvenil hacia el servicio militar (algo que empezaba a reflejarse en las ofertas electorales de los partidos sobre la duración de la mili). La preocupación gubernamental era evidente. El ritmo de crecimiento de las ya abultadas cifras de objetores acumulados desde 1977 podría acelerarse todavía más, en medio de aquel boicot a la ley y cuando empezaban los rumores sobre una eventual "amnistía encubierta" (o pase a la reserva de "los objetores históricos"), un borrón y cuenta nueva.

La situación pareció quedar desbloqueada en 1987, cuando el Tribunal Constitucional rechazó el recurso del Defensor del Pueblo ${ }^{34}$. El Gobierno ya podía aplicar la ley, pero sabía que no iba a ser fácil. Cuando calculó la fuerza de la movilización que tenía enfrente, despreció dialécticamente a los grupos rupturistas tachándolos de insolidarios, y halagó a los que no optaban por la desobediencia (como

\footnotetext{
${ }^{32}$ En otros países, como Francia e Italia, una estrategia parecida había llevado a los objetores a la cárcel: Rafael Ajangiz, Servicio Militar obligatorio en el siglo XXI: cambio y conflicto, (Madrid: CIS, 2003), p. 173.

${ }^{33}$ Fernando Rodrigo, La objeción de conciencia en España, (Madrid: Instituto de la Juventud. Ministerio de Cultura, 1986).

${ }^{34}$ José Luís Gordillo, "El tribunal constitucional da un paso al frente", Mientras Tanto, 33 (1987: 29-32); Francisco Javier de Lucas Martín, Ernesto Jaime Vidal Gil, María José Añón Roig, "La objeción de conciencia según el Tribunal Constitucional: algunas dudas razonables", Revista General del Derecho, 21 (1988: 81-93).
} 
la Asociación de Objetores de Conciencia, AOC, que se había creado en 1985 en Barcelona) ${ }^{35}$. Pero la cuestión, al haberse demorado tanto, seguía siendo peliaguda. La objeción ya no era aquel problema político que enojaba a los mandos militares, se había convertido en un problema social. Para quitarse de en medio a los de la carta colectiva, se eximiría de la mili a unos 22.000 objetores en incorporación aplazada. Y para hacer cumplir la Prestación Social Sustitutoria (PSS) se elaboraría un Reglamento. El antimilitarismo respondió desobedeciendo. La década de 1980, subdividida en dos etapas cruciales, no había transcurrido en balde para un movimiento que crecía y se radicalizaba.

\section{$3^{\text {a }}$ etapa (1983-1986): Un movimiento antimilitarista y antimili}

En los primeros años 80 llegaron nuevos militantes a colectivos de objeción que seguían contando con la presencia de liderazgos de largo recorrido. Muchos habían radicalizado su objeción contra toda conscripción en el sentido que se había acordado en Landa y, frente a quienes actuaban meramente como "grupos de objetores" preocupados con esa problemática, convenían en que el MOC, además de trabajar la eventual regulación legal de la objeción, debía enriquecer su repertorio con "la objeción postmili" (mediante la devolución de las cartillas militares), con la objeción fiscal y con acciones y discursos feministas contra la incorporación de la mujer a las Fuerzas Armadas $^{36}$. Algunos pocos, como el GAMBA, empujaban hacia una campaña antimili que incorporara a la izquierda revolucionaria y que posicionara al MOC a favor de la insumisión. Pero otros albergaban alguna esperanza respecto del PSOE, un partido que había asumido ciertas propuestas normativas del MOC. No hubo que esperar mucho para que el panorama se dilucidara. En 1983, los grupos del MOC, en toda su variedad (unos más escorados hacia la noviolencia, otros más inclinados hacia el antimilitarismo, algunos todavía organizados en torno a los servicios civiles autogestionarios y otros más dispuestos a dar un empujón juvenil al rechazo del servicio militar), cuando leyeron el borrador de la Ley de Objeción de Conciencia del PSOE, salieron definitivamente del

\footnotetext{
${ }^{35}$ Carlos Ángel Ordás García, "El Movimiento de Objeción de Conciencia en la década de 1980", Ayer, 116 (2019-4: 282, 194).

${ }^{36}$ MOC. En legítima desobediencia. Tres décadas de objeción, insumisión y antimilitarismo, (Madrid: Traficantes de Sueños, 2002), p. 105.
} 
impasse.

En principio, además de reanimar la agitación antimilitarista, el MOC no renunció a hacer pedagogía política contra la nueva ley y echó mano de los "puntos básicos" que debía contener una ley mínimamente aceptable. Para el MOC, la ley del PSOE creaba el indeseable "tribunal" -el CNOC- que iba a juzgar la conciencia del objetor sin reconocer las motivaciones políticas, ni las objeciones sobrevenidas de los soldados en la mili, ni mucho menos las objeciones en tiempo de guerra, apuntalando, por lo demás, una Prestación Social Sustitutoria (PSS) que en nada se parecía a un servicio civil por la paz, que no ocultaba su relación con estructuras de naturaleza militarista y que estaba pensada como un castigo para el objetor, porque iba a ser de mayor duración que la mili y porque abarcaría un elenco de actividades que debían realizar las personas en paro.

Pero lo más relevante para el futuro inmediato del MOC fue el hondo calado del debate ideológico y estratégico que se suscitó ${ }^{37}$. El MOC confrontó sus diferencias y constató su propio proceso de decantación por un antimilitarismo radicalmente contrario a toda conscripción, aunque eso estuviera ocurriendo entre discrepancias y sobre todo con contradicciones políticas, incluso después de haber puesto en marcha con gran éxito la campaña de la "carta colectiva" (lo que de por sí ya era una opción profundamente rupturista y desobediente), desavenencias que en cierto sentido iban a dilatarse hasta el II Congreso (Madrid, 1986), donde, a diferencia de lo acordado en la declaración ideológica del I Congreso de 1979, la apuesta por la abolición de toda conscripción (militar o civil) no añadiría ninguna salvedad respecto de una ley o un servicio civil que pudieran ser aceptables. En el lenguaje político del MOC, entre 1983 y 1986, se hizo habitual una palabra -insumisión- que, no siendo nueva pues se había usado desde la Transición, en adelante ocuparía la centralidad del discurso de todo el movimiento antimilitarista.

El MOC pasaba el umbral de no retorno en la apuesta por la desobediencia civil como principal herramienta de acción política. Esta radicalidad cerraba otros caminos, lógicamente. En principio, excluía a un sector minoritario, en realidad no militante, que aceptaba la ley del PSOE como un avance. Pero también iba a dejar de lado a quienes preferían presionar al gobierno sin anteponer la desobediencia, esperando conseguir una

\footnotetext{
37 Un análisis de la trascendencia de esa evolución ideológica en: Pedro Ibarra (ed), Objeción e insumisión. Claves ideológicas y sociales, (Madrid: Fundamentos, 1992), pp. 34 y ss.
} 
modificación parcial de la ley (era la línea política que desembocaría en la creación de la AOC y que podemos definir aquí como "reformista" si la ponemos en contraposición con un MOC que en su II Congreso se definía como movimiento antimilitarista "solidario con otras luchas revolucionarias", para referirse fundamentalmente al ecologismo y al feminismo $)^{38}$. En cambio, empatizaba con grupos del movimiento autónomo y okupa, con colectivos anarquistas que más adelante impulsarían la propuesta de "insumisión total", y sobre todo con los Mili KK, que empezaban a constituirse como el otro gran puntal del movimiento antimilitarista. El primer colectivo Mili KK, que se había fundado en Barcelona en 1984, sirvió de guía para la izquierda radical. Cuando en 1986 terminó la campaña anti-OTAN existía una red de colectivos Mili KK -en Euskadi y Navarra se llamaron coordinadoras Kakitzat- que logró multiplicar la agitación antimilitarista poniendo el acento en el mensaje antimili y en la implicación de la juventud trabajadora y estudiantil con la objeción de conciencia y las luchas antimilitaristas ${ }^{39}$. Por su parte, las izquierdas independentistas observaban el desarrollo del movimiento antimilitarista y antimili, pero desde la distancia política e incluso con manifiesta contrariedad.

\section{$4^{\mathrm{a}}$ etapa (1987-1988): Hacia la insumisión}

Tras recibir el espaldarazo del Tribunal Constitucional, el gobierno, queriendo por fin aplicar la ley, optó por "institucionalizar" todo lo posible, a través de los Consejos de Juventud, el acceso a la información sobre la objeción de conciencia, para "restarle protagonismo a los colectivos de objetores" que venían realizando esa labor desde siempre ${ }^{40}$. Además, decidió el pase a la reserva de los objetores acumulados durante una década (medida que sería oficial en diciembre de 1989), mientras que el CNOC dejaba de admitir la carta colectiva. El movimiento antimilitarista acusó el golpe denunciándolo como una maniobra forzada del gobierno por desactivarlo $\mathrm{y}$ descabezarlo. La respuesta se notó en las calles, con más protestas, mientras que en las

\footnotetext{
${ }^{38}$ MOC. En legítima desobediencia. Tres décadas de objeción, insumisión y antimilitarismo, (Madrid: Traficantes de Sueños, 2002), pp. 305-307.

39 Enric Prat, "Antimilitarismo y movimiento antimili”, Inprecor, 58 (enero 1988). Versión on line: https://cdn.vientosur.info/Capitulo\%208\%20PDFs/Doc.\%208.43.pdf

40 Cristino Barroso Ribal, ¿Para qué sirve la "mili”? Funciones del servicio militar obligatorio en España, (Madrid: Siglo XXI, 1991), p. 100.
} 
asambleas se preparaba la desobediencia civil. La campaña de insumisión estaba dando sus primeros pasos.

En esa tesitura, celebrando las dificultades del gobierno para hacer cumplir sus propios plazos cada vez que anunciaba la puesta en marcha de la PSS, se idearon respuestas colectivas que resituaran al movimiento de objeción en la vía de la insumisión a la mili, mientras se esperaba hacer factible también la insumisión a la PSS. En 1988, entre quienes podían dar el paso hacia la insumisión, había objetores cuya carta colectiva no había sido admitida, otros que no mandaban instancia alguna al CNOC, además de los objetores a media mili y los reobjetores ${ }^{41}$. La "reobjeción" creó polémica -no fue consensuada en el MOC, pero los discrepantes tampoco la vetaron ${ }^{42}$ y, sin embargo, implicó a más de 2.000 objetores. "Reobjetar" significaba renunciar al reconocimiento del CNOC para quedar disponible como recluta y, en ese caso, objetar de nuevo. Se pretendía contrarrestar el efecto legal de la llamada "amnistía encubierta", es decir, el pase a la reserva de los objetores de entre 1977 y 1987. Pero el CNOC, barruntando el alcance de aquella táctica insumisa, ignoró las reobjeciones, excepto unas pocas que algunos antimilitaristas lograron camuflar de manera individual.

El movimiento antimilitarista, entre 1987 y 1989, respondió al gobierno con un repertorio de acciones pacíficas a la vez que radicales: sentadas, cadenas humanas, marchas de antorchas, encadenamientos y concentraciones de todo tipo (no pocas frente a los gobiernos militares), las actividades del 15 de mayo (Día Internacional de la Objeción de Conciencia), campañas contra el sorteo de mozos, acciones de denuncia contra la Cruz Roja (desde que en 1988 ofertó 500 plazas de objetores), y hasta con exitosas huelgas estudiantiles (como las que promovieron las coordinadoras Kakitzat). La capacidad movilizadora de los Mili KK se hizo notar. También hubo protestas contra la prisión militar de algunos objetores sobrevenidos o a media mili (como José Manuel Fierro, declarado en 1988 "preso de conciencia" por Amnistía Internacional), y ocupaciones pacíficas de sedes del PSOE y edificios gubernamentales, devoluciones de cartillas militares, presentaciones de "reobjetores" y un largo etcétera de pasacalles y

\footnotetext{
${ }^{41}$ Jordi García (ed.), Con razón, insumisión, (Madrid: Talasa ediciones S.L. 1990, p. 143.

${ }^{42}$ La reobjeción se valora de manera ambivalente en la memoria del MOC, o como una de las tácticas "muy forzadas" (según Ramón Carratalá) o como una decisión coherente de amnistiables que querían seguir en la lucha y no "librarse de nada" (para Fernando González), véase: MOC. En legítima desobediencia. Tres décadas de objeción, insumisión y antimilitarismo, (Madrid: Traficantes de Sueños, 2002), p. 99 y p 195.
} 
actividades lúdicas y festivas, muchos conciertos, exposiciones, cenas de solidaridad, jornadas de debate, montajes teatrales... Se puso en valor la coordinación en una atmósfera a veces envuelta de rivalidad (por ejemplo, Mili KK respetaba, pero no asumía ideológicamente la noviolencia que orientaba todas las posiciones del MOC, desde el enfoque del internacionalismo hasta las respuestas a la represión policial ${ }^{43}$.

Entre el verano y el otoño de 1988, a través de un proceso asambleario algo caótico que el MOC organizó en asambleas zonales, el movimiento se fue decantando por la desobediencia colectiva ${ }^{44}$. En las Jornadas Antimilitaristas de Zaragoza, celebradas en noviembre, grupos del MOC y de Mili KK asumieron la insumisión ${ }^{45}$. En la práctica, el movimiento antimilitarista estaba preparando la insumisión, lo que le restaba fuerza en otros cometidos. Sin embargo, el clima del momento parecía incitar al sobresfuerzo. No se abandonaban del todo otras actividades que identificaban los idearios de cada grupo: todos los colectivos redoblaron su apoyo a iniciativas contra la militarización del territorio (campos de tiro, bases militares, etcétera); los Mili KK, de manera específica, crearon las "oficinas de defensa del soldado", lo que provocaba discusiones acerca de la coherencia de la iniciativa; y el MOC, donde cabían hasta tres grupos de la Internacional de Resistentes a la Guerra (Euskadi, Cataluña y Madrid) ${ }^{46}$, seguía con la educación para la paz y la objeción fiscal y mantenía un debate interno sobre la noción misma de desmilitarización (incluyendo la relación "mujeres y antimilitarismo", cuando, por lo demás, desde 1988, tuvo que comenzar una campaña

\footnotetext{
${ }^{43}$ Carlos Ángel Ordás García, "El Movimiento de Objeción de Conciencia en la década de 1980", Ayer, 116 (2019-4: 282, 277-303 En este artículo puede leerse un análisis documentado sobre el MOC como colectivo vertebrador del movimiento antimilitarista durante los años 80 , sin obviar las rivalidades que mantuvo con los colectivos Mili KK. El autor otorga una importancia capital al impacto del referéndum de la OTAN tanto en la agenda del CNOC y del gobierno socialista como en el desarrollo del movimiento antimilitarista (incluyendo el proceso de socialización juvenil que hubo de vivirse dentro de él y en relación con otros movimientos sociales, como el feminista, el ecologista, de okupación, etcétera).

${ }^{44}$ La asamblea más concurrida se celebró en Orio, donde el MOC acordó nítidamente dar el paso definitivo hacia la insumisión, lo que quedó reflejado en los medios (Navarra Hoy, 30 de agosto de 1988).

${ }^{45}$ Pedro Ibarra, Objeción e insumisión. Claves ideológicas y sociales, (Madrid: Fundamentos, 1992), p. 53.

${ }^{46}$ Desde la primera campaña de 1971 se buscó el apoyo de movimientos sociales europeos y de líderes con proyección internacional (como Marco Pannella, del Partito Radicale italiano). Esas relaciones se hicieron más sistemáticas durante los años 80 , cuando el MOC consiguió obtener cierto protagonismo e influencia en la War Resisters' International (WRI-IRG, Internacional de Resistentes a la Guerra, en cuyo Consejo estuvo como representante del MOC el abogado bilbaíno Rafael Sainz de Rozas), además de hacerse notar en la European Bureau for Conscientious Objetion (Oficina Europea para la Objeción de Conciencia) y en los encuentros anuales del International Conscientious Objetors Meeting (ICOM, Encuentro Internacional de Objetores de Conciencia), etcétera. Véase: Rafael Sainz de Rozas, "La objeción a nivel internacional", Papeles para la Paz, 38 (1990), pp. 143-185.
} 
contra la incorporación de la mujer a las Fuerzas Armadas). Pero, en cualquier caso, preparar la insumisión requeriría un plus de activismo.

\section{AÑOS 90: INSUMISIÓN Y CRISIS DEL SISTEMA DE RECLUTAMIENTO}

El llamado "salto de enero" de 1989, que iba a ser el inicio de la campaña de insumisión, tuvo que aplazarse un mes. El compás de espera ayudó a aumentar la expectación mediática sobre el tan anunciado "enfrentamiento" antimilitarista". Considerando las fechas de los sucesivos reemplazos, MOC y Mili KK tenían previstas varias presentaciones simultáneas, en distintas capitales, de objetores que ya habrían desobedecido el llamamiento a filas, es decir, insumisos a la mili que, en buena lógica, tendrían que ser apresados. El 20 de febrero se presentaron los primeros 57 insumisos, de los cuales, 11 fueron capturados en las semanas siguientes. En la segunda presentación de abril hubo 60 insumisos y 2 detenciones. Y en junio llegó la tercera, con 75 insumisos y 4 detenidos. El primer balance parecía alentador para la insumisión. En el primer año, mientras el número de insumisos superaba el centenar que los grupos antimilitaristas se habían propuesto, la contabilidad de la reacción represiva del gobierno era más modesta: se detuvo al $8.5 \%$ de los insumisos y la estancia media en prisión preventiva no pasó de 18 días. Además, sólo se celebró un consejo de guerra, en noviembre y en Barcelona, bajo la presión de una multitud que vitoreaba a los dos procesados. Mientras que el movimiento preparaba un 1990 aún más caliente, el gobierno iba a remolque.

El 1 de diciembre de 1989 llegó la "amnistía” de más de 27.000 objetores antiguos que habían sido reconocidos antes de que se reglamentara la PSS ${ }^{48}$. ¿Cuántos nuevos harían desobediencia civil? Ése era el verdadero reto interno del movimiento. La insumisión estaba diseñada, pero, como toda movilización, tenía que construirse. Y para eso era fundamental llevar la iniciativa y perseverar con los procedimientos y objetivos de la campaña: cuidar la buena imagen de la acción noviolenta, cosechar apoyo social,

\footnotetext{
${ }^{47}$ La prensa aventuraba cifras relevantes de objetores que se declararían insumisos desde enero, por ejemplo: 179 en Navarra (Navarra Hoy, 6 de noviembre de 1988), 150 en Euskadi (DEIA, 21 de diciembre de 1988), etcétera.

${ }^{48}$ Enric Prat, Moviéndose por la paz. De Pax Christi a las movilizaciones contra la guerra, (Barcelona: Hacer, 2003), p. 239.
} 
no perder de vista el impacto estatal de lo que se hiciera en cualquier territorio, rentabilizar la represión eludiendo la criminalización y apelando a valores colectivos como la paz y el desarme. Todo ello conectaría con la animadversión juvenil hacia la mili (que crecía en toda España y a pasos agigantados en Cataluña, Euskadi y Navarra $)^{49}$. Las autoridades tendrían que detener a los desobedientes o asumir que el principio de autoridad quedara quebrantado, abriéndose una brecha por la que entraran más y más desobedientes, lo que pondría al sistema de reclutamiento en situación crítica.

Es verdad que el desafío insumiso fue contestado desde el principio con detenciones y consejos de guerra, y más adelante, con un reguero de juicios civiles y encarcelamientos en prisiones provinciales. Pero los datos hablaban por sí solos de un contraste muy llamativo desde el principio: hasta diciembre de 1991 se celebraron 13 consejos de guerra en total, cuando por esas fechas ya se habían declarado más de 1.200 insumisos al servicio militar. Será desde 1992 cuando vaya en aumento el número de insumisos en prisiones provinciales: 17, en 1992; 157 en 1993; 165 en 1994; 182 en 1995 y 315 en 1996. Pero aumentaba mucho más el número de insumisos no enjuiciados. En 1994 se calculaba un total de 10.800 insumisos $^{50}$.

Por lo tanto, la autoridad se ejerció con un alcance tan limitado, que la grieta de 1989 quedó abierta para ensancharse. La respuesta judicial dispersa y titubeante, incluso contradictoria, que a unos parecía selectiva mientras que para otros daba pábulo a la impunidad de quien desobedecía una obligación legal, indicaba algo mucho más profundo que todo eso: se había desencadenado un debate sobre un conflicto social -el del rechazo popular de la mili obligatoria- que nunca se había afrontado en España. Con el éxito de la insumisión como música de fondo, por un lado, los partidos empezaron a enfocar la cuestión de la mili como un conflicto que debía tener un reflejo en la batalla electoral; y por otro, distintas instancias de poder chocaron entre sí al enfrentarse a un movimiento social que había acumulado experiencia, organización y prestigio social. Las elites se vieron sobrepasadas. La trascendencia social y política de aquel método pacífico de lucha, la desobediencia civil, en aquellas coordenadas históricas, estaba

\footnotetext{
${ }^{49}$ Ya en noviembre de 1989 una encuesta de los Consejos de la Juventud había detectado que el 66,6 por ciento de los jóvenes vascos y navarros rechazaba cualquier tipo de servicio militar (El Independiente, 7 de noviembre de 1989).

${ }^{50}$ https:/elpais.com/diario/1994/11/16/espana/784940413 850215.html
} 
siendo enorme: "concedió relevancia a un problema que hasta mediados de los años ochenta afectaba a un pequeño colectivo" $"$.

Mientras que la campaña de insumisión se veía arropada por el "colchón social" que los grupos antimilitaristas habían conseguido construir, la PSS se desarrollaba boicoteada. El gobierno empezó desbordado y sin recursos para la PSS, aunque contaba con el beneficio simbólico de la colaboración de los objetores de la AOC, con implantación sobre todo en Barcelona y Vizcaya (más tarde, esta organización protagonizaría otra vertiente del conflicto, a través de un tipo de desobediencia condicionada que llevó a juicio a algunos objetores que se ausentaron del servicio civil cuando su duración alcanzaba el mismo tiempo que el servicio militar) ${ }^{52}$. Echando mano de ayuntamientos afines y Juventudes Socialistas, además de Cruz Roja, INSERSO, Protección Civil y algunas universidades, el ejecutivo socialista a duras penas consiguió que en marzo de 1989 pudiera comenzar la actividad de medio centenar de plazas, para alcanzar después logros muy insuficientes: a finales de 1991, con más de 92.000 objetores legalmente reconocidos, apenas 4.500 realizaban la PSS. La inoperancia hubo de provocar fricciones interministeriales: altos cargos del Ministerio de Defensa señalaron con malestar al Ministerio de Justicia que el incremento de los objetores se debía a la inoperancia de la PSS $^{53}$. El gobierno no podía dejar de ver el reflejo de la insumisión en ese panorama tan crítico ${ }^{54}$. Las cifras de objetores aumentaban (llegando a pasar del 37\% del contingente militar del año 1994). El Ministerio de Justicia, reconociendo que la PSS era un fracaso, anunció la reforma de la misma ${ }^{55}$. Aun así, en 1995, la bolsa de objetores en espera pasaba de 200.000.

Entre 1990 y 1991 el fenómeno de la insumisión había ido ganando fama y se agrandaba, más aún en la sociedad vasca (el 52\% de los 1.383 jóvenes que se habían

\footnotetext{
${ }^{51}$ Víctor Sampedro, Movimientos sociales: debates sin mordaza. Desobediencia civil y servicio militar (1970-1996), (Madrid: Centro de Estudios Constitucionales, 1997), p. 303.

${ }^{52}$ La reforma legal de la mili en 1991 supuso una rebaja en su duración, de 13 a 9 meses, mientras que la PSS duraba 13. Más de 50 objetores siguieron la campaña de la AOC y abandonaron la PSS a los 9 meses de estar realizándola. Algunos fueron condenados, normalmente a 4 meses y 1 día (Enric Prat, Moviéndose por la paz. De Pax Christi a las movilizaciones contra la guerra, (Barcelona: Hacer, 2003), pp. 242-243.

${ }^{53}$ https://elpais.com/diario/1990/11/12/espana/658364423_850215.html

54 El ministro de Justicia, Enrique Múgica, advirtió a los objetores insumisos, a los que tachó de "insolidarios", que sobre ellos caería todo el peso de la ley $(A B C, 8$ de marzo de 1991).

551994 comenzó con 57\% más de solicitudes de objeción que 1993 (El Mundo, 23 de febrero de 1994).
} 
declarado insumisos entre 1989 y 1990 eran de Euskadi y Navarra ${ }^{56}$. Cuando, de repente, el conflicto del Golfo Pérsico vino a agigantarlo. En 1991, en medio de las protestas por la participación española en la guerra, la insumisión eclosionó como fenómeno social. La sociedad rechazó contundentemente el hecho de que fueran movilizados soldados de reemplazo. A los insumisos presos en calabozos militares se unirían algunos desertores. Los colectivos antimilitaristas se convirtieron en altavoces de un descontento social que agudizaba el rechazo juvenil a la mili y hacía crecer la objeción de conciencia. Y en medio de todo eso pudo verse al ejército presidiendo consejos de guerra contra insumisos.

El gobierno se decidió por cambiar la Ley del Servicio Militar, reduciendo el tiempo de mili y trasladando los casos de insumisión a la jurisdicción ordinaria. A los tribunales civiles empezaría a llegar una dosis redoblada de insumisión, una insumisión hipertrofiada, y una sensación de caos: todos los insumisos a la mili hasta diciembre de 1991 serían condenados a 1 año (hasta un máximo de 6), y todos los insumisos a la PSS (más los insumisos a la mili que surgieran en adelante) debían ser condenados como ya estaba previsto en la LOC, a penas de 2 años, 4 meses y 1 día (hasta un máximo de 6). La disparidad de horizontes penales también afectaba al movimiento insumiso. Intentando homogeneizar los tiempos de permanencia en prisión, los insumisos a la mili, que previsiblemente iban a ser condenados por la justicia civil al mínimo de 1 año, aceptaban peticiones fiscales de 18 meses $^{57}$.

El primer juicio civil a insumisos a la PSS se realizó en Albacete, en enero de 1991. Reapareció la imagen de la multitud pacifista jaleando a los acusados frente a la Audiencia manchega ${ }^{58}$. El movimiento insumiso volvió a mostrar su músculo incluso en una capital pequeña. Desde entonces seguiría un goteo de juicios. Destacó sobremanera la cantidad de juicios y sentencias condenatorias en la Audiencia de Navarra, pero, en general, no hubo una alta judicialización y primaron las disparidades y las disconformidades de las decisiones judiciales. Hasta 1992 la mayoría de los insumisos recibieron sentencias de menos de un año. Incluso hubo algunas absoluciones (como la

\footnotetext{
${ }^{56}$ La prensa destacaba en junio de 1990 que el porcentaje de insumisos de Navarra era diez veces superior a la media estatal (Navarra Hoy, 18 de junio de 1990).

57 "Insumiso acepta la petición fiscal de 18 meses en solidaridad con los encarcelados" (El Mundo, 11 de diciembre de 1992).

${ }^{58}$ https:/elpais.com/diario/1991/01/21/espana/664412409 850215.html
} 
de Iñaki Arredondo en marzo de 1992 por parte del juez madrileño Calvo Cabello, cuyo impacto en el debate fue apabullante). En 1993 continuó la "lotería de condenas" " La cárcel, por lo demás, sirvió a partir de 1993 de revulsivo de la campaña de insumisión. El "plante" fue la respuesta a lo que el ministerio de Justicia presentaba como mera modificación del reglamento penitenciario para que los insumisos quedaran pronto en tercer grado, algo que el movimiento antimilitarista interpretó como una maniobra política para desactivar el potencial de la insumisión en la crisis de reclutamiento.

Las medidas del gobierno no evitaron que la insumisión siguiera teniendo presencia mediática e influencia social. La insumisión coadyuvaba al crecimiento de la objeción legal, lo que objetivamente contribuía a que la PSS fuera en gran medida irrealizable, por falta de plazas habilitadas ${ }^{60}$. A la altura de 1994, tras admitir que se arrastraba un considerable déficit de reclutas en los cuarteles, el gobierno asumió que la insumisión se había convertido en "un problema de Estado"61. En 1995, el ejecutivo de Felipe González quiso dar otra salida al conflicto con la reforma del Código Penal. La insumisión, de facto, no sería penada con cárcel, porque las penas privativas de libertad quedaban reducidas a menos de 2 años. Sin embargo, se imponían multas y privación de otros derechos: penas de inhabilitación para ejercer la función pública, de entre 10 a 14 años para los insumisos a la mili y de entre 8 a 12 para los insumisos a la PSS, y prohibición de ejercer cargos públicos y de obtener ayudas o becas, lo que el movimiento antimilitarista denunció como "muerte civil". Se reactivó el "colchón social", incluso con declaraciones institucionales de municipios y universidades a favor de la no cooperación con la obligación legal. Destacó EUDIMA, la red de

\footnotetext{
${ }^{59}$ MOC. En legítima desobediencia. Tres décadas de objeción, insumisión y antimilitarismo, (Madrid: Traficantes de Sueños, 2002, p. 202.

${ }^{60}$ Así se sostiene gracias a los estudios sociológicos que se hicieron entonces, de los que puede leerse un buen balance en: Xavier Aguirre, Rafael Ajangiz, Pedro Ibarra y Rafael Sainz de Rozas, La insumisión, un singular ciclo histórico de desobediencia civil, (Madrid: Tecnos, 1998. Se publicó un estudio estadístico de la "gestión del sistema de prestación sustitutoria" que demostraba la evolución contradictoria del mismo, un "colapso" que no se pudo solventar: en 1995, cuando había 39.666 objetores "prestacionistas" y apenas se ofertaban 59.015 "puestos de prestación", la cifra de "objetores en espera" llegó a 190.397 (Rafael Ajangiz, Servicio Militar obligatorio en el siglo XXI: cambio y conflicto, (Madrid: CIS, 2003, p. 181).

${ }^{61}$ El ministro de Defensa, Julián García Vargas, tras descalificar a los insumisos por "insolidarios" y "extravagantes", lamentó que el fenómeno de la objeción y la insumisión estuviera provocando un "problema de Estado" que llevaba "a España a un callejón sin salida" (El País, 29 de mayo de 1994).
} 
ayuntamientos insumisos vascos creada en $1996^{62}$. Sin embargo, el cambio más sustancial llegaría cuando el PP, tras las elecciones de 1996, al pactar con CiU y PNV, se vio obligado a anunciar el fin de la mili para 2003. Desde ese momento, la insumisión perdía visibilidad a pesar de seguir penalizada (de hecho, mientras que los nuevos insumisos empezaban a ser castigados con penas de inhabilitación, los insumisos anteriores ya condenados seguían en las prisiones civiles, hasta 1998, año en el que el gobierno Aznar promulgó una nueva Ley de Objeción de Conciencia) ${ }^{63}$. La noticia del fin de la mili generó una actitud social ambivalente para el movimiento antimilitarista: por un lado, se podía cantar victoria porque los cálculos, aunque imposibles de medir con precisión, hablaban de unos 20.000 insumisos como colofón de un largo proceso de movilización antimilitarista y desobediencia $\operatorname{civi1}^{64}$, y porque la sociedad había asumido el fin de la mili mientras otorgaba poca credibilidad a la PSS $^{65}$; pero por otro, se estaba reduciendo ostensiblemente la influencia del discurso antimilitarista en el debate sobre el papel de los ejércitos y el modelo de defensa, dentro del cual, los colectivos antimilitaristas habían conseguido introducir propuestas pacifistas transversales sobre "defensa civil", y otras más radicales, como la "defensa popular noviolenta" "66. Así las cosas, el MOC se decidió por continuar con la desobediencia civil de otra manera, con "la insumisión en los cuarteles".

\footnotetext{
${ }^{62}$ La fiscalía de San Sebastián presentó una querella "por asociación ilícita con el ánimo de delinquir" que no prosperó, a pesar de contar con el visto bueno del Fiscal General del Estado (El País, 16 de diciembre de 1997). La disputa judicial por la cuestión insumisa estaba en relación con el choque político que protagonizaban Madrid y Vitoria, puesto que EUDIMA contaba con cierta complicidad institucional del Gobierno vasco (https://elpais.com/diario/1998/11/06/paisvasco/910384813 850215.html).

${ }^{63}$ Ley 22/1998, de 6 de julio, reguladora de la Objeción de Conciencia y de la Prestación Social Sustitutoria (https://www.boe.es/buscar/act.php?id=BOE-A-1998-16132\&tn=6).

${ }^{64}$ Xavier Aguirre, Rafael Ajangiz, Pedro Ibarra y Rafael Sainz de Rozas, La insumisión, un singular ciclo histórico de desobediencia civil, (Madrid: Tecnos, 1998; Rafael Ajangiz, "Objeción de conciencia, insumisión y movimiento antimilitarista", Mientras Tanto, 91-92 (2004: 139-154).

${ }^{65}$ Tras aprobarse una nueva LOC (que derogaba la reforma de 1994 y fijaba la misma duración a la PSS que a la mili, 9 meses), se aceptaba la situación crítica que atravesaba la conscripción. En la práctica se exoneraba de la PSS a miles de objetores que llevaban más de tres años esperando a tener plaza y terminaban su servicio aquellos que llevaban 9 meses realizándolo (El País, 27 de julio de 1998).

${ }^{66}$ La idea de "defensa popular noviolenta" fue debatida en el MOC recurrentemente desde sus orígenes: Utopía Contagiosa, "Modelos de defensa y alternativas noviolentas", Mambrú n 52 (primavera 1995).
} 


\section{$5^{\text {a }}$ etapa (1989-1996): La insumisión como movimiento}

El movimiento antimilitarista, cuando preparaba la campaña de insumisión, estaba compuesto por una extensa red de colectivos del MOC y Mili KK. Esa fue su estructura básica hasta 1996. En algunas provincias había grupos libertarios adscritos a la idea de "insumisión total". Las izquierdas independentistas también se incorporaron, entre 1990 y 1991, cuando la insumisión ya era una idea fuerza que abrazaban los jóvenes vascos y catalanes ${ }^{67}$. Convertida en fenómeno social, más aún cuando los "plantes" penitenciarios espolearon la solidaridad con los insumisos presos, en la movilización insumisa surgieron grupos que seguían las dinámicas de las organizaciones dinamizadoras de la campaña, pero no se adscribían a ninguna de ellas.

Las publicaciones coetáneas y las memorias de activistas y colectivos de este movimiento inducen a pensar que, para que se diera el impulso inicial de 1989, tuvieron que vislumbrar e interiorizar, como meta realizable, la posibilidad de acabar con la conscripción en España. La preparación de la campaña de insumisión proyectaba ambición y firmeza en torno a cinco objetivos operativos: 1) Defender que la insumisión era factible pero también legítima como respuesta colectiva contra la conscripción, sin aceptar que la PSS fuera una alternativa desmilitarizadora, porque un servicio civil, además de ser un castigo, sustituía y sustentaba aquello contra lo que se objetaba: la mili y el militarismo. 2) Concienciar hacia dentro y concienciar hacia afuera (a los aliados del propio movimiento) acerca de la fortaleza política de uno de los pilares básicos de la desobediencia civil y del propio movimiento de objeción desde siempre: que el coste político de la represión debía "pagarlo" el poder que reprimía, preparándose para soportar la respuesta punitiva y revertirla contra el gobierno ${ }^{68}$. 3) Desacreditar a las entidades que acogían objetores mientras que otros eran castigados. 4) Conseguir un gran apoyo social que añadiera legitimidad y sirviera de ayuda colectiva y soporte personal a los insumisos presos. Y 5) Contar con insumisos dispuestos para empezar.

El último objetivo era la prueba de fuego que no podían improvisar. La insumisión era un desafío al ejército, al Estado. En la memoria del movimiento podía

\footnotetext{
${ }^{67}$ En marzo de 1990, Jarrai hizo público su propio enfoque del apoyo a la insumisión, propugnando la “objeción política abertzale” de los jóvenes vascos al servicio militar (Egin, 17 de marzo de 1990).

${ }^{68}$ Era, en definitiva, el tipo de acción noviolenta que habían practicado Gandhi y Martin Luther King, y que habían teorizado Gene Sharp y Noam Chomsky, entre otros. Véase: Gene Sharp. The Politics of Noviolent Action, (Boston: Porter Sargent Publishers, 3 volúmenes, 2000, $1^{\text {a }}$ edición de 1973); Noam Chomsky, El pacifismo revolucionario, (México: Siglo XXI, 1973).
} 
parecer otro reto más, como el de 1985, pero se respiraba un aire distinto, como de "enfrentamiento" final. La movilización se socializó rápidamente. Llegaron a él personas y colectivos con culturas y tradiciones políticas muy dispares, con ideas radicales pero diferentes. Por eso, los portavoces del movimiento no dejaron de afirmar que lo acordado en las asambleas de los grupos que coordinaban la movilización tendría que desarrollarse sin concesión alguna a la ocurrencia, la espontaneidad y la improvisación.

Entre 1989 y 1996, la campaña de insumisión verificó, básicamente con el impulso y la coordinación estatal del MOC y Mili KK, todas las líneas de actuación que se habían proyectado, entre ellas, una muy importante: la construcción de un "colchón social" compuesto por los propios colectivos antimilitaristas y las coordinadoras o plataformas creadas con ese propósito, más los grupos de apoyo a cada insumiso y un conjunto de herramientas de expresión de la solidaridad, incluyendo las autoinculpaciones judiciales, reservadas para personalidades del mundo de la música, el arte y la cultura en general, y representantes de instituciones diversas, entidades de todo tipo, movimientos sociales, sindicatos, partidos, asociaciones, $\mathrm{ONG}$, etcétera.

Hasta los números tendrían que ser valores compartidos, algo que no asumieron, o no comprendieron del todo, aquellas fuerzas nacionalistas que se incorporaron a la movilización cuando ya estaba en marcha o incluso avanzada. Aunque las cifras de insumisos fueran muy dispares, territorio a territorio, y hubiera más posibilidades de hacer efectiva la movilización mediante presentaciones públicas de insumisos en ciudades como Bilbao, Barcelona o Pamplona, o eventualmente en Madrid y Zaragoza, en Sevilla, Valladolid, Gijón o Valencia, entre otras capitales más o menos populosas, la campaña de insumisión, como tal ejercicio de desobediencia civil a un paquete legislativo que afectaba a toda la sociedad española, debía tener visibilidad a nivel estatal. Entenderlo así, y realizarlo mediante acciones públicas y noviolentas, resultó ser crucial para que el éxito político de la insumisión fuera prácticamente inmediato, de lo que daba buena cuenta el impacto mediático, tanto en los medios locales y autonómicos como en los de ámbito estatal. Los riesgos de la desobediencia a veces avivaron y con el tiempo fueron diluyendo las antipatías recíprocas del MOC y los colectivos Mili KK (y Kakitzat), más aún cuando juntos dieron el paso hacia una mayor radicalización con el "plante" al tercer grado penitenciario, una estrategia que no fue secundada por todos los insumisos, quedando unos en $2^{\circ}$ grado y otros en tercer grado penitenciario, pero cuya 
repercusión fue estatal, a pesar de las desproporciones numéricas entre territorios, y consiguió galvanizar a todo el movimiento ${ }^{69}$. Esa fase, la que va de 1993 a 1997, fue tan intensa, que lógicamente hubo de desgastar a los colectivos más implicados. No obstante, rechazaron la "muerte civil" resultante del Código Penal de 1995 y cosecharon apoyos y hasta declaraciones institucionales de no colaboración: a los insumisos que habían sido juzgados todavía con la legislación anterior, se les daba la opción de elegir o la cárcel o la inhabilitación70. Incluso surgieron iniciativas nuevas dirigidas hacia fuera y hacia dentro del antimilitarismo, como la "insumisión rosa" que auspiciaba el movimiento gay ${ }^{71}$. Sin embargo, el anuncio del fin del servicio militar obligatorio sí que barruntaba una desactivación real del movimiento insumiso. Fue entonces cuando se tomó la última iniciativa: "la insumisión en los cuarteles". El movimiento de objeción e insumisión, ciertamente debilitado y desgastado, pero con prestigio y capital político aún suficientes, entró en su última etapa.

\section{$6^{a}$ etapa (1997-2002): Insumisión en los cuarteles y fin de ciclo}

Con el anuncio del fin de la mili, el ejército, que, por aquellas fechas, sobre todo con las intervenciones humanitarias, intentaba recuperar prestigio social, parecía haber quedado apartado del foco de atención, como si no tuviera nada que ver con esa conscripción que se estaba desmoronando. Para reorientar la situación, y para reorientarse como movimiento, se preparó otra modalidad de insumisión. La nueva campaña comenzó su andadura en marzo de 1997, cuando cinco insumisos que habían desertado de sus cuarteles en enero y febrero se presentaron delante del Gobierno Militar de Madrid ${ }^{72}$. Se reconocen ahí varios de los elementos habituales en las campañas de objeción e insumisión, aunque, para hacer de la necesidad virtud, esta vez

\footnotetext{
${ }^{69}$ Desde el primer "plante", realizado el 13 de diciembre de 1993 y protagonizado por 45 insumisos de las prisiones de Pamplona, Vizcaya, Asturias, Tenerife, Albacete y Valladolid, una abrumadora mayoría de los quebrantamientos de condena se dieron en Navarra (El País, 14 de diciembre de 1993).

${ }^{70}$ Desde Pamplona se lanzó un mensaje con gran relevancia política, dado que su prisión albergaba el mayor número de insumisos en $2^{\circ}$ grado penitenciario: se rechazó con contundencia la nueva modalidad de penalización, la mayoría de los ya condenados preferían seguir cumpliendo las penas del viejo código (Diario de Navarra. 19 de mayo de 1996).

${ }^{71}$ Juicio a un insumiso que defendió su homosexualidad frente a los valores militaristas y homófobos del ejército (Diario de Noticias, 12 de mayo de 1996).

${ }^{72}$ https://elpais.com/diario/1997/03/08/espana/857775616 850215.html
} 
se expresaba a través de una acción centralizada, en la capital del Estado, lo que restaba importancia a su carácter claramente minoritario en favor de la difusión del mensaje político. No obstante, la nueva estrategia caminó acompañada de presentaciones públicas y acciones directas contundentes en instalaciones militares, protagonizadas por activistas del movimiento antimilitarista ${ }^{73}$. La campaña tenía dos grandes propósitos que eran plenamente coherentes con la larga trayectoria del MOC: 1) Un objetivo estratégico, para que la desobediencia civil siguiera siendo la herramienta principal en la lucha contra la obligatoriedad de la mili mientras no fuera abolida. La "insumisión en los cuarteles" sería minoritaria pero en un contexto de crisis terminal de la conscripción, con un enorme crecimiento de la objeción legal, realidad numérica que se agravaba si se contaba con el incremento de las peticiones de prórroga, lo que indicaba que casi un millón de jóvenes intentaban aplazar su incorporación, esperando pasar definitivamente a la reserva en $2002^{74}$. La conscripción se derrumbaba a ojos vistas, dejando patente que el desafecto social hacia el ejército seguía siendo muy grande, hasta el punto de que la juventud no se sentía atraída tampoco por el modelo de ejército profesional que ya se estaba construyendo ${ }^{75}$. Y 2) Un objetivo ideológico, para que el conflicto abierto por la objeción y la insumisión continuara en sus coordenadas antimilitaristas, redirigiendo el foco hacia los ejércitos, los cuarteles y la jurisdicción militar, los consejos de guerra y las prisiones militares, denunciando sus funciones reales y simbólicas en la militarización social y en la preparación de la guerra (por ejemplo, y sin ir más lejos, obligando a los jóvenes a realizar servicios de armas).

La insumisión en los cuarteles, formalmente, era una deserción: el recluta firmaba su incorporación dentro del cuartel, para, tras abandonarlo como soldado, no regresar y declarar públicamente su objeción de conciencia e insumisión. De esa manera continuó vivo el ciclo de movilización que había comenzado en 1971, otra vez con

\footnotetext{
73 'Strip-tease' insumiso en el Gobierno Militar de Bilbao (El País, 23 de marzo de 1997); "Detenidos diez insumisos por ocupar el cuartel de Aizoáin" (Diario de Navarra, 27 de abril de 1997).

${ }^{74}$ El País destacaba: "A medida que se acerca el final de la mili, y a pesar de que la caída de la natalidad ha reducido sustancialmente el número de varones en edad militar, aumenta la cifra de objetores y de beneficiarios de prórroga" (https://elpais.com/diario/1998/11/13/espana/910911623 850215.html).

${ }^{75}$ Carlos Navajas, "La profesionalización de las Fuerzas Armadas durante la primera legislatura popular", Historia del presente, 4 (2004: 184-209); Carmen Gordon-Nogales "La transición desarmada: objetores, política y prensa en la transformación de las Fuerzas Armadas en la España democrática", Amnis: Revue de Civilisation Contemporaine de l'Université de Bretagne Occidentale (4: 2004).
} 
consejos de guerra y con casi 30 insumisos en la prisión militar de Alcalá-Meco ${ }^{76}$. Entre 1999 y 2000 se reguló el proceso legal de suspensión de la mili, previsto para 2003, pero muy pronto pudo verse que la presión continuaba y que de facto la mili ya no existía. En noviembre del año 2000 se realizó el último sorteo de quintos de la historia de España. El Gobierno aprobó el 9 de marzo de 2001 el decreto que "suspendía" la mili a partir de diciembre de ese año ${ }^{77}$. En noviembre de 2000 el MOC publicaba una "Carta abierta sobre el fin de la mili" en la que manifestaba su "gran alegría" y su satisfacción por el éxito de 30 años de lucha, recordando, eso sí, que la desaparición del servicio militar no era un fin en sí mismo, sino "una etapa en la lucha por la abolición del ejército y el militarismo social" ${ }^{, 78}$.

La despenalización del delito de insumisión no llegaría a ser efectiva hasta 2002, con reformas penales retroactivas que afectaban a 4.000 insumisos y "siete desertores" ${ }^{\prime 7}$. De esa manera, el 25 de mayo, pudieron ser puestos en libertad los cuatro insumisos que en esa fecha aún permanecían encarcelados (3 en la prisión militar de Alcalá de Henares y 1 en la de Basauri $)^{80}$. Se ponía fin a un ciclo de movilización que había usado la desobediencia civil desde el principio hasta el final. A nadie debía extrañar que el último día, entre quienes acudieron a aplaudir la libertad de los últimos objetores insumisos, estuviera el primero de ellos, Pepe Beunza.

\section{CONCLUSIONES}

Interpretar la importancia de esta movilización antimili y antimilitarista en España implica conocer al movimiento por dentro, pero siempre en relación con los

\footnotetext{
${ }^{76}$ Los 15 insumisos en los cuarteles de 1997 eran de Galicia, Elche, Bilbao, Pamplona, Valencia, Valladolid, Madrid, Sevilla, Palma de Mallorca y Barcelona, doce del MOC y dos de la Asamblea de Objeción de Conciencia de Galicia (ANOC). En años sucesivos hubo también insumisos-desertores de Menorca y Cáceres. Véase MOC. En legítima desobediencia. Tres décadas de objeción, insumisión y antimilitarismo, (Madrid: Traficantes de Sueños, 2002, pp. 243, 254.

${ }^{77} \mathrm{https://elpais.com/diario/2001/03/09/espana/984092421} \mathrm{850215.html}$

${ }^{78}$ La "carta abierta" en: MOC. En legítima desobediencia. Tres décadas de objeción, insumisión y antimilitarismo, (Madrid: Traficantes de Sueños, 2002, pp. 297-299.

79 https://www.abc.es/espana/abci-gobierno-despenaliza-insumision-y-desercion-caracter-retroactivo200202010300-75644_noticia.html

${ }^{80}$ https://elpais.com/diario/2002/05/26/espana/1022364010_850215.html
} 
cambios en la estructura de oportunidad política, entre el tardofranquismo y a lo largo de la democracia, porque, de una u otra manera, en todos esos tiempos, a lo largo de seis etapas claramente identificables, se abrieron posibilidades para la movilización. Sus hitos inicial y final sitúan a este nuevo movimiento social entre 1971 y 2002. En el año de inicio, 1971, el movimiento arrancó con la campaña pública (también internacional) de apoyo al primer objetor de conciencia del franquismo que, no siendo Testigo de Jehová, alegaba ante los jueces del consejo de guerra motivos políticos basados en el pacifismo y la noviolencia. Y en el año de cierre, 2002, se decretaba el fin de la mili y con ella también terminaba la campaña de insumisión. Hablamos de dos campañas políticas separadas por tres décadas y dos regímenes políticos diferentes: la dictadura, que lógicamente negaba y castigaba el derecho a la objeción de conciencia, y la democracia, que reguló la objeción de conciencia no como un derecho sino como un motivo de exención del servicio militar obligatorio, una restricción -en parte derivada de la presión del ejército durante el proceso de democratización-, que contribuiría sobremanera, a diferencia de lo que ocurría en otros países europeos, a la radicalización del movimiento de objetores en un sentido anti mili pero también antimilitarista. Aquella radicalidad era tan peculiar - por noviolenta y desobediente- que durante años no fue comprensible para la cultura política de izquierda.

La eclosión de este movimiento social en los primeros años de la década de 1990 no se entiende sin analizar la trascendencia del boicot a la Ley de Objeción entre 1985 y 1987, cuando se dejó notar el doble efecto acumulativo (proactivo para los objetores y reactivo para el Estado) de las dos dinámicas movilizadoras del movimiento de objeción, cada una de las cuales con una doble vertiente, interna y externa: $1^{\text {a }}$ ) La primera dinámica, que se había desarrollado durante la segunda mitad de los 70 , se desplegó hacia dentro cuando el MOC logró estructurarse como coordinadora de múltiples colectivos, y hacia fuera, al esgrimir la desobediencia civil para bloquear una ley de la UCD que hubiera sido demasiado temprana para la incipiente movilización anti mili. $2^{\text {a })}$ Y la segunda, la de 1985, se dirigió también hacia dentro, porque el movimiento de objeción crecía y se diversificaba con la creación de Mili KK, posicionándose radicalmente contra toda conscripción, y sobre todo hacia fuera, con la campaña de la "carta colectiva".

En cualquier caso, todas las campañas, incluyendo las más emblemáticas (la de Pepe Beunza y la de insumisión) fueron coherentes con la misma apuesta estratégica: la 
desobediencia civil. Aquella herramienta rupturista se fue poniendo en práctica con diferentes formas y en distintas etapas: cuando se logró la retirada del proyecto de ley de UCD, cuando se usó la "carta colectiva" contra la ley del PSOE y, por supuesto, cuando en 1989 comenzó la campaña de insumisión al servicio militar y la PSS, con el colofón de la insumisión en los cuarteles. Fue la apuesta estratégica por la desobediencia civil lo que logró aquilatarlo como movimiento social en todo su largo ciclo de movilización.

\section{BIBLIOGRAFÍA}

Agüero, Felipe. Militares, civiles y democracia. La España postfranquista en perspectiva comparada. Madrid: Alianza, 1995.

Aguirre, Xavier; Ajangiz, Rafael; Ibarrra, Pedro; Sainz de Rozas, Rafael. La insumisión, un singular ciclo histórico de desobediencia civil, Madrid: Tecnos, 1998.

Ajangiz, Rafael. "Objeción de conciencia, insumisión y movimiento antimilitarista", Mientras Tanto, 91-92 (2004: 139-154).

-- Servicio Militar obligatorio en el siglo XXI: cambio y conflicto, Madrid: CIS, 2003.

Barroso Ribal, Cristino. ¿Para qué sirve la "mili”? Funciones del servicio militar obligatorio en España, Madrid: Siglo XXI, 1991.

Casals, Xavier. La Transición española. El voto ignorado de las armas, Barcelona: Pasado y Presente, 2016.

Castañar Pérez, Jesús. Breve historia de la acción noviolenta, Madrid: Pentapé, 2010.

-- Teoría e Historia de la Revolución Noviolenta, Virus: Barcelona, 2014.

Chomsky, Noam. El pacifismo revolucionario, México: Siglo XXI, 1973.

Cockburn, Cythia. Antimilitarisme. Dinàmiques polítiques i de gènere dels moviments per la pau, Barcelona: Pagès editors, 2014.

Díez Nicolás, Juan. Identidad nacional y cultura de defensa, Madrid: Síntesis, 1999).

García, Jordi (ed.). Con razón, insumisión, Madrid: Talasa ediciones S.L. 1990.

Gordillo, José Luís, "El tribunal constitucional da un paso al frente", Mientras Tanto, 33 (1987: 29-32).

Gordon-Nogales, Carmen. "La transición desarmada: objetores, política y prensa en la transformación de las Fuerzas Armadas en la España democrática", Amnis: Revue de Civilisation Contemporaine de l'Université de Bretagne Occidentale (4: 2004).

Ibarra, Pedro. “Un nuevo movimiento social”, Papeles para la Paz, 38 (1990): pp. 229237.

-- Manual de sociedad civil y movimientos sociales, Madrid: Síntesis, 2005.

Ibarra, Pedro (ed). Objeción e insumisión. Claves ideológicas y sociales, Madrid: Fundamentos, 1992.

Jiménez, Jesús. La objeción de conciencia en España, Madrid: Cuadernos para el Diálogo, 1973.

Lafuente, José Luis; Viñas, Jesús. Los objetores. Historia de una acción, Madrid: Cares, 1977. 
Lederach, John Paul. Els anomenats pacifistes. La noviolència a l'Estat espanyol (1983), Barcelona: Pagès editors, 1983.

López-Martínez, Mario. "Historia de la paz en acción: el pacifismo de los salones a las calles (1889-1939)", Vínculos de Historia, n ${ }^{\circ} 7$ (2018), pp. 79-96 http://vinculosdehistoria.com/index.php/vinculos/article/view/vdh_2018.07.05).

Martín, Francisco Javier de Lucas; Vidal Gil, Ernesto Jaime; Añón Roig, María José. "La objeción de conciencia según el Tribunal Constitucional: algunas dudas razonables", Revista General del Derecho, 21 (1988), pp. 81-93.

Mcadam, Doug; Mccarthy, John D. y Zald, Mayer N. Movimientos sociales: perspectivas comparadas, Madrid: Istmo, 1999.

MOC. En legítima desobediencia. Tres décadas de objeción, insumisión y antimilitarismo, Madrid: Traficantes de Sueños, 2002

Molinero, Carme; Ysàs, Pere. La Transición: Historia y Relatos, Madrid: Siglo XXI, 2018.

Navajas, Carlos. "La profesionalización de las Fuerzas Armadas durante la primera legislatura popular", Historia del presente, 4 (2004: 184-209).

Núñez Florencio, Rafael. Militarismo y antimilitarismo en España (1888-1906), Madrid: CSIC, 1990.

Oliver Araujo, Joan. La objeción de conciencia al servicio militar, Madrid: Universitat de les Illes Balears-Cívitas, 1993.

Oliver Olmo, Pedro. La utopía insumisa de Pepe Beunza. Una objeción subversiva durante el franquismo, Barcelona: Virus, 2002.

Oliver Olmo, Pedro. "El movimiento pacifista en la transición democrática española", en Rafael Quirosa-Cheyrouze (ed), La sociedad española en la Transición. Los movimientos sociales en el proceso democratizador, Madrid: Biblioteca Nueva, Madrid, pp. 271-286.

-- "Los iniciadores del movimiento de objetores de conciencia (1971-1977)", en Manuel Ortiz Heras (Coord.), Culturas politicas del nacionalismo español: del franquismo a la transición, Madrid: Los libros de la Catarata, 2009, pp. 219-244.

Ordás García, Carlos Ángel. "El Movimiento de Objeción de Conciencia en la década de 1980", Ayer, 116 (2019-4: 282, 277-303).

-- "La soledad de los primeros pacifistas. Incomprensión de las izquierdas y apoyos de sectores proconciliares" (comunicación presentada en VIII Encuentro Internacional de Investigadores del Franquismo, Barcelona, 21 y 22 de noviembre de 2013), https://www.dropbox.com/sh/evt0ds930y05p11/AADoutYAIaAHAYQ9vzw_Eui Qa?preview $=\mathrm{Ord} \% \mathrm{C} 3 \% \mathrm{~A} 1 \mathrm{~s} \% 2 \mathrm{C}+\mathrm{Carlos}+\% \mathrm{C} 3 \% 81$ ngel.pdf.

Ordás García, Carlos Ángel. "Traidores a la patria. Objetores e Insumisos en España, 1958-1991", Clio \& Crimen, 14 (2017: 209-226).

-- "L'objecció de consciència durant el franquisme i la Transició. Dissidència política i xarxa de suport", Franquisme \& Transició, 4 (2016: 41-87).

Ortega, Pere. La societat noviolenta. Converses amb Pepe Beunza, Barcelona: IcariaICIP, 2012.

Pérez Ledesma, Manuel. “ $<<$ Nuevos $>>$ y $<<$ viejos $>>$ movimientos sociales", en Carme Molinero (ed.), La transición, treinta años después, Barcelona: Península, 2006, pp. 117-151.

Prat, Enric. “Antimilitarismo y movimiento antimili", Inprecor, 58 (enero 1988). https://cdn.vientosur.info/Capitulo\%208\%20PDFs/Doc.\%208.43.pdf 
-- Moviéndose por la paz. De Pax Christi a las movilizaciones contra la guerra, Barcelona: Hacer, 2003.

Rius, Xavier. La objeción de conciencia: motivaciones, historia y legislación actual, Barcelona: Editorial Integral, 1988.

Rodrigo, Fernando. La objeción de conciencia en España, Madrid: Instituto de la Juventud. Ministerio de Cultura, 1986.

Sainz de Rozas, Rafael. "La objeción a nivel internacional", Papeles para la Paz, 38 (1990): pp. 143-185.

-- "Razones y vivencias del objetor y del insumiso", Papeles. Cuestiones internacionales de paz, ecología y desarrollo, CIP, 54 (1995): pp. 37-44.

Sampedro, Víctor. Movimientos sociales: debates sin mordaza. Desobediencia civil y servicio militar (1970-1996), Madrid: Centro de Estudios Constitucionales, 1997.

Seco Serrano, Carlos. Militarismo y civilismo en la España contemporánea. Madrid: Instituto de Estudios Económicos, 1984.

Sharp, Gene. The Politics of Noviolent Action, Boston: Porter Sargent Publishers, 3 volúmenes, 2000 ( $1^{\text {a }}$ edición de 1973).

Tarrow, Sidney. El poder en movimiento. Los movimientos sociales, la acción colectiva y la política, Madrid: Alianza, 2004.

Utopía Contagiosa. "Modelos de defensa y alternativas noviolentas", Mambrú n 52 (primavera 1995).

VV.AA. Objeción de conciencia: otro servicio, Barcelona: Cuadernos edebé, Ediciones Don Bosco, 1977. 